\title{
The effect of Voki application on students' academic achievements and attitudes towards English course
}

\author{
Serkan Yeşilbağ ${ }^{1}$ (D) Özgen Korkmaz ${ }^{2}$
}

Received: 25 May 2020 / Accepted: 25 June 2020 / Published online: 8 July 2020

(C) Springer Science+Business Media, LLC, part of Springer Nature 2020

\begin{abstract}
The purpose of this research is to assess the effect of Voki, a tool of web 2.0 on students' academic achievement and attitudes towards English courses. The study group of this research, using a quasi-experimental design with a pretest-posttest control group, consists of 5th-grade students at a public secondary school in the Merkezefendi district of Denizli province, Turkey. In the experiment group, the "Party Time" unit was taught via Voki-supported activities while the same unit was taught according to the current curriculum without using Voki in the control group. The entire process of the experiment lasted 6 weeks. In the study, the academic achievement test and attitude scale towards English courses (Cronbach's Alpha = 0.92) were used to measure dependent variables. The normality distributions of the data were examined after the data were collected, and it was decided to analyze the data through the mean, standard deviation, and independent-sample t-test. According to the results of the research, there was an increase in the achievement test scores of both groups in the English lesson. However, a statistically significant difference was observed in the speaking section of the experimental group in the achievement test. There was no significant difference between the attitudes of the groups towards English courses. It is therefore recommended that English teachers should use Voki application in speaking activities.
\end{abstract}

Keywords Web 2.0 · Voki · Foreign language teaching · Student's achievement · Student' attitudes $\cdot$ Technology-supported learning

\section{Özgen Korkmaz}

ozgenkorkmaz@gmail.com

Serkan Yeșilbağ

serkanyesilbag@gmail.com

1 Department of Instructional Technology, Amasya University, Institute of Science, Amasya, Turkey

2 Faculty of Technology, Department of Computer Engineering, Amasya University, Amasya, Turkey 


\section{Introduction}

In today's globalizing world, relations between societies are increasing day by day (Brown, McIlwraith, \& González, 2020) and its effect is visible in all areas (Karakuş, 2013). Countries strive to establish international relations and networks to seek a way for political, social, and economic development (Punthumasen, 2007). In this context, the need to speak foreign languages has an important place in today's world (Çınar, 2007), and learning a foreign language has become a necessary and important skill (Roumen \& Grego, 2012).

Today, different programs are being implemented in all educational institutions from primary school to university and ways to achieve success are being sought in foreign language teaching in Turkey (Demirel, 2019). Although the increasing need for foreign language learning is well known, it can be said that a successful level has not been achieved in the process from primary education to higher education (Paker, 2006). Many graduates who have taken language education from primary to higher education cannot even communicate at the beginner level, and in the current system, this situation has led to the training of individuals who do not understand what is spoken in a foreign language (English), cannot express their feelings and thoughts orally and in writing but try to understand the written text with the help of words (Paker, 2012). Many factors cause this obvious challenge in language teaching (Demirpolat, 2015). Songbatumis (2017) stated the difficulties experienced in language learning as follows; Students' lack of adequate vocabulary knowledge could be a possible reason why the student does not understand the lesson. In Mohammed's (2018) study, he identified the difficulties arising from the methods, materials used in foreign language teaching, the role of the teacher, the performance of students, and the learning environment. Suna \& Durmuşçelebi (2013) mentioned the problems arising from foreign language teaching policy and planning; the problems arising from taking overseas programs as they are. Çarıkcıoglu (2019) stated the general problem experienced by English teachers working in Turkey: disinterested students, frequent changes in the curriculum, baseless changes in the program, insufficient content of textbooks, and insufficient regulation. Bodur \& Arikan (2017) indicated that the target language is not spoken around the language learners and therefore they are not exposed to almost any target language in their daily lives; and language learners are not exposed to the mass media's programs in the target language. In Acat \& Demiral's (2002) study, they linked problems such as students' lack of motivation, motivation problems while learning and factors that motivate language learning.

\subsection{Technology-supported approaches in language learning}

When the literature was examined, it was observed that there were problems in foreign language teaching and many factors had an impact on these problems. This situation brought different approaches and methods in foreign language learning. Abdullah (2015) emphasized the importance of collaborative learning with an appropriate strategy, positive social interaction, a language-rich classroom, the inclusion of multicultural resources in the curriculum. Kaynar (2019) stated that education including the necessities of the time and making the most of technological opportunities can positively affect the teaching and learning process and the success rate. Gömleksiz \& 
Düşmez (2005) focused on more effective language teaching by transferring technology to the classroom environment, that is, by integrating technology into foreign language lessons. The development of computer technology, the widespread use of personal computers and the internet have enabled individual language learning. Thus, multimedia (digital audio, image, graphic, animation, and music) started to be used in foreign language teaching under the name of Computer Assisted Education (CAE) (Boz \& Çoban, 2015). We can define computer aided teaching as the use of technology in the teaching process, an environment in which learning takes place, a method blended with technology that increases motivation, allows the students to learn at their own pace and individually (Ușun, 2000; Șahin \& Yıldırım, 1999). Of course, with developing and changing technologies, CAE transformed, and new concepts introduced such as online learning, blended learning, flipped-classroom applications, and web 2.0 into the literature.

\subsection{Web 2.0 technologies in education}

Today, web environments that enable the technology to be easily integrated into the teaching process, can be created using dynamic web technologies presented as a web interface. These technologies are referred to as "Web 2.0 applications or web 2.0 technologies (Korucu \& Cakir, 2015). In the Cambridge Online Dictionary, Web 2.0 is defined as a name given to all Internet features and websites that allow users to create, modify, and share Internet content (Cambridge Dictionary, 2020). "Web 2.0", a concept invented by O'Reilly Media in 2004, has been described as the second generation of web-based interactions, applications, and communities. It is specified as a shift from a read-only internet to a writable internet (O'Reilly, 2005).

Web 2.0 tools, which also enable the creation of online digital content, have developed rapidly in recent years and have been widely used in the teaching process (Durusoy, 2011). Developments in Internet technology have led to the use of new ways in foreign language education (Levy, 2009). Learning environments covering four basic skills (listening, speaking, reading, and writing) in language teaching can be created with online-based Web 2.0 tools. (Baș \& Yıldırım, 2018). Web 2.0 tools can help students acquire language skills in foreign language education in terms of providing a natural learning environment, the opportunity to collaborate, and tracking their learning (Arıkan \& Özel, 2015). Interaction is crucial for language acquisition, and Web 2.0 technologies may enable students to interact with each other (İnce \& Akdemir, 2013). Many applications can be found within the scope of Web 2.0 technology. Today, technology plays an important role in education as well as in many other fields. The emergence of Web 2.0 technology, in particular, has been a facilitator and encouraging for the integration of technology into education (Al-Kathiri, 2015). Web 2.0 technologies increase students' interests and motivation towards the course, as well as contributing to the development of four basic skills in English. (Yunus, Kwan, \& Noriah, 2012). When the studies on the web 2.0 tools used in the English courses are examined in the literature, the positive effects of these tools on the educational environment can be seen (Setyawati \& Azizaturrohmah, 2016; Arikan \& Özel, 2015; Ince \& Akdemir, 2013). One of the web 2.0 tools that are effective in English language teaching and compatible with the lesson is Voki (Yona \& Marlina, 2014). 
In Ramdani's (2018) study on the use of Voki to support first-grade students learning of English as a foreign language, he found that the application was useful. He emphasized that the reason for this is that students can access the cloud-based library and file sharing from anywhere, anytime with the Voki application, feel comfortable while learning languages through Voki, increased speech motivation, exposure to speaking English outside the classroom, cooperate with teachers and friends, and get feedback. Zargaryan (2012) examined the effect of Voki application on students' speaking skills. In her semi-experimental study consisting of 24 participants, the experimental and control groups were almost at the same level before the application. The data of the research were obtained through a pretest-posttest, interview, and a questionnaire. The study concluded that Voki is useful in improving the speaking skills of foreign language students. Manty, Yunus, Badusah, \& Shah (2017) conducted action research on the use of Voki as a teaching tool in foreign language learning and students 'perceptions of using Voki to improve their speaking skills. The findings showed that Voki helped students improve their speaking skills in terms of fluency and pronunciation. Picardo (2009) stated that Voki contributes positively to students 'use of conjunctions in a foreign language lesson and also helps them to have a wider vocabulary. He also stated that thanks to the voice recording feature of Voki at home, students had more confidence in speaking Spanish and their participation in the lessons increased. Setyawati and Azizaturrohmah (2016) investigated the utility of Voki as an educational tool, on teaching and learning to speak. He has emphasized that Voki improves the teaching process by using a different way for the teacher; it is a new speaking practice and motivational training tool for the student. He stated that a student practicing speaking through Voki would be more fluent. Fun and interesting aspects of applications such as Voki can be useful not only in foreign language learning but also in acquiring basic language skills (Yazar, 2019). In Özdemir's (2017) work on how digital technologies can be used in teaching Turkish to foreigners, he embodied Podcasts on Voki and Vocaroo. He also stated that students who have problems with pronunciation in foreign language learning can practice pronunciation through Voki in extracurricular activities and can repeat it many times. Besides, he stated that Voki can improve the student's writing skills by writing the voiceover section. Baş \& Yıldırım's (2018) investigated the effect of using web 2.0 tools such as Voki, Pixton, and Padlet on students' motivation and creativity in teaching Turkish to foreigners. The study group consisted of 10 students who learned Turkish at the B1 level. As a result of the application, these tools had a positive effect on student motivation and creativity.

However, although Web 2.0 tools are used in many educational institutions, it is stated that there is not enough research on online learning environments in initial language teaching (Chakowa, 2018). Considering all these circumstances, in this study, it is aimed to determine the effect of Voki application used for 5th grade English lesson the "Party Time" unit on students" academic achievement and attitudes towards courses. This study also draws attention to the use of the Voki, one of Web 2.0 tools in foreign language lessons, to gain four basic skills (listening, reading, speaking, writing) following the general-purpose and basic principles of National Education, to communicate in the target language, to develop a positive attitude towards courses. It is believed that the integration of web 2.0 technologies like Voki tool described in this paper in foreign language 
teaching will lead to the development of newer tools and to change in teaching methodology of foreign languages.

\subsection{Research question}

Does the Voki application used for the 5th grade English lesson "Party Time" unit have an effect on students' academic achievement and attitudes towards English courses?

\subsubsection{Sub-problems}

- Does teaching via Voki affect students' reading, writing, listening, and speaking skills towards the "Party Time" unit?

- Does teaching via Voki affect students' attitudes towards English courses?

\section{Methods}

\subsection{Research design}

In this research, a semi-experimental design with a pretest-posttest control group was used. Experimental designs are used to trace cause-and-effect relationships between defined variables (Büyüköztürk, 2014). Since one class was assigned as an experiment and the other class as a control group, it can be said that the research pattern is a semiexperimental design with a pretest-posttest control group (Karasar, 2004). The test is applied before and after the experimental process to determine the difference between the two groups that are assumed to be equal (Büyüköztürk, 2009). In this context, the two classes in the school were determined randomly and an effort was not made to equalize the classes (Table 1).

\subsection{Study group}

The study group of the research consisted of 5th-grade students studying in a secondary school in the Merkezefendi district of Denizli, Turkey during the 2019-2020 academic year. Experimental and control groups were determined by a simple random sampling method. Fifty-nine students, 32 of whom were girls and 27 of whom were boys, participated in this study. The experimental group consisted of 29 students, 17 of whom were girls, and 12 of whom were boys; the control group consisted of 30

Table 1 Experimental Design

\begin{tabular}{llll}
\hline Groups & Pre-test & Experimental manipulation & Post-test \\
\hline $\begin{array}{l}\text { Experimental } \\
\text { Group }\end{array}$ & $\begin{array}{c}\text { Academic Achievement } \\
\text { Test }\end{array}$ & Voki application & $\begin{array}{c}\text { Academic Achievement } \\
\text { Test }\end{array}$ \\
Control Group & $\begin{array}{c}\text { Attitudes towards English } \\
\text { Scale }\end{array}$ & $\begin{array}{c}\text { Teaching without Voki } \\
\text { application }\end{array}$ & $\begin{array}{c}\text { Attitudes towards English } \\
\text { Scale }\end{array}$ \\
\hline
\end{tabular}


students, 15 of whom were girls, and 15 of whom were boys. The students in the groups were around 11 years old. The groups were homogeneous regarding students' parents' similar socio-economic backgrounds. The school's academic achievement was above average when compared with other secondary schools in the Merkezefendi district of Denizli, Turkey. The distribution of the study group by gender was summarized in Table 2.

\subsection{Data collection tools}

In the research process, two different data collection tools were used to collect data. These were the academic achievement test and attitude scale towards English courses. Features of these tools were presented in the following titles:

\subsubsection{Academic achievement test}

Listening, speaking, reading, and writing skills are a whole in language teaching. Therefore, when teaching a language as a means of communication, these skills have to be handled together (Demirel, 1990). The measuring tool has four sections including communicative skills (listening, speaking, reading, and writing) was developed to measure the acquisitions of the 5th grade English lesson "Party Time" unit. Scale scoring was stated as the highest 25 points for each skill and the highest score for a total of four sections is 100 .

A video entitled "Monster Shopping Trip" following the general-purpose and basic principles of National Education and unit acquisitions was watched through LearnEnglish Kids website to measure the listening skills of the students. Five sentence completion questions in that activity were applied without making any changes to test students' listening comprehension. Each question was worth exactly 5 points. The highest score from this section was 25 . To measure reading-comprehension skills, a reading text was prepared by the researcher considering the cognitive competences of 5 th-grade students. Five open-ended questions were asked about the reading text. In order to determine the relevance, observable, and measurable of each question in the examination, the opinions of two 5th grade English teachers at the same school and an expert were taken. Each question was worth exactly 5 points. The highest score from this section was 25 . For the evaluation of writing skills, the writing activity on the (British Council, 2020) website was applied without making any changes to the students. Students were asked to dream about a perfect birthday and write about this birthday party. The answer to each question in the written text was evaluated as 5

Table 2 Distribution of groups by gender

\begin{tabular}{lccc}
\hline & Girl & Boy & Total \\
\hline Exp. Group & 17 & 12 & 29 \\
Control Group & 15 & 15 & 30 \\
Total & 32 & 27 & 59 \\
\hline
\end{tabular}


points. The highest score from this section was 25 . To clarify the section of writing, the following questions were prepared, and students were asked to write a short text by answering these questions:

- Where is it?

- Who is coming?

- Is there a theme?

- What games do you play and what activities do you do?

- What presents do you get?

Four questions which compatible with the unit achievement were taken from the British Council website to measure speaking skills. The questions are:

- When is your birthday?

- How do you celebrate your birthday?

- What is the best birthday present you have ever got?

- What do you do at birthday parties?

Paker \& Höl's (2012) speech rating scale in their research, was used in the assessment of the speech exam. Evaluation: It was applied in the range of 1 and 5 points in five criteria as "content, organization, vocabulary, fluency, accuracy" (Table 3).

5.Very good; 4.Good; 3.Adequate; 2.Inadequate; 1.Poor

To determine the reliability of the measurement instrument described above, the evaluations were conducted independently by the researcher and one of his colleagues. The correlations between the scores were calculated. Pearson's correlation coefficient is defined as the scoring consistency of the two evaluators. These correlation values are considered as the reliability coefficient (Balc1, 2001). The findings were summarized in Tables 4 and 5.

Pearson correlation analysis was applied to measure the reliability of the academic achievement test. A positive correlation was found between the results of the pre-test evaluation $(r=0.978 ; p=, 000<0.05)$.

Pearson correlation analysis was applied to measure the reliability of the academic achievement test. A positive correlation was found between the results of the post-test evaluation $(r=0.989 ; p=, 000<0.05)$.

Table 3 Oral exam assessment sheet

\begin{tabular}{|c|c|c|c|c|c|c|}
\hline $\begin{array}{l}\text { Oral exam } \\
\text { assessment } \\
\text { sheet }\end{array}$ & $\begin{array}{l}\text { Content } \\
\text { (5 } \\
\text { point) }\end{array}$ & $\begin{array}{l}\text { Organization } \\
\text { (5 point })\end{array}$ & $\begin{array}{r}\text { Vocabulary } \\
\text { (5 point) }\end{array}$ & $\begin{array}{l}\text { Fluency } \\
\qquad \begin{array}{l}(5 \\
\text { point })\end{array}\end{array}$ & $\begin{array}{l}\text { Accuracy } \\
(5 \\
\text { point })\end{array}$ & Total \\
\hline
\end{tabular}


Table 4 Academic achievement pre-test independent evaluators' consistency

\begin{tabular}{lc}
\hline 1. Evaluator & 2. Evaluator \\
\hline Listening & $1000^{* *}$ \\
Reading & $1000^{* *}$ \\
Writing &, $956^{* *}$ \\
Speaking &, $796^{* *}$ \\
Total &, $978^{* *}$ \\
\hline
\end{tabular}

$\mathrm{N}: 59, * \leq 0,05, * * \leq 0,01$.

\subsubsection{Attitude scale towards English courses}

Students' attitudes towards English courses were evaluated with the "Attitude Scale towards English Courses" developed by Baș (2012). The scale consists of 27 items and five factors. These are sensitivity (6 items), consciousness (5 items) importance ( 8 items), methods, and materials ( 5 items), language and, culture ( 3 items). The scale which was developed as a five-point Likert type ("strongly agree", "agree", "neutral", "disagree" and "strongly disagree"), has 15 positive and 12 negative statements. The items on the scale were rated as the most negative 1, the most positive 5. As a result of the reliability and validity study applied to the scale; Cronbach's Alpha and SpearmanBrown split-half test correlations were calculated, and Cronbach's alpha value was found to be 0,92 . it was also calculated that other sub-dimensions of the scale ranged between 0,77 and 0,93 . The split-half test correlation of the scale was found to be 0,83 . It seems that all factors are consistent with each other. According to this result, we can say that the scale is a reliable scale that can be used in determining the behavior and attitude towards English courses.

\subsection{Experimental procedure}

The application was carried out over 6-week during the second semester of the 20192020 school year. The "Party Time" unit was chosen from the fifth grade English coursebook for public schools, which was implemented by the Turkish Ministry of National Education. After the 3-week experimental application process was carried out with face-to-face education, in the 4th week of the application, the schools were

Table 5 Academic achievement post-test independent evaluators' consistency

\begin{tabular}{lc}
\hline 1. Evaluator & 2. Evaluator \\
\hline Listening & $1000^{* *}$ \\
Reading & $1000^{* *}$ \\
Writing &, $983^{* *}$ \\
Speaking &, $957^{* *}$ \\
Total &, $989^{* *}$ \\
\hline
\end{tabular}

$\mathrm{N}: 59, * \leq 0,05, * * \leq 0,01$. 
interrupted as of 16 March 2020 due to the ongoing situation with the coronavirus (Covid-19) and the education process started to be carried out by the distance education through the internet and television channels. For this reason, the weekly curriculum was restructured for the experimental practice. The experimental process was continued by the researcher through online lessons via the Zoom meeting program. The lessons were taught as an hour per week on different days for both groups. Supportive studies were carried out through the EBA system (Education Information Network) to manage the process efficiently. Besides, WhatsApp groups were used to maintain contact with the students and their parents. Technical support and follow-ups were provided when necessary. The high socio-economic level of the parents and their positive view of the distance education process helped to manage the process more efficiently. The scope of implementation includes the following achievements:

- Listening

- E5.7.L1. Students will be able to understand simple permission requests and responses.

- Speaking

- E5.7.S1. Students will simply be able to ask for permission and give response.

- E5.7.S2. Students will be able to use basic greeting and leaving expressions.

- E5.7.S3. Students will be able to use ready-made utterances to express obligations.

- E5.7.S4. Students will be able to state the date of an event.

- E5.7.S5. Students can express and respond their thanks.

- Reading

- E5.7.R1. Students will be able to understand short texts with visual aids such as cartoons, posters, and birthday cards.

- Writing

- E5.7.W1. Students will be able to prepare a birthday invitation card.

In the experiment group, the "Party Time" unit was taught via Voki-supported activities while the same unit was taught according to the current curriculum without using Voki in the control group. The "Party Time" unit was taught at the same time in both groups. In the experimental group, the application of Voki was introduced to the students by using the interactive board before the application. User manuals prepared by the researcher were handed out. A Voki Classroom was created. Usernames and passwords were given to each student to login to the Voki Classroom. In addition to the use of Voki presentation tools, students were given homework every week through the Voki application and asked to present in the lesson. Applications in the experimental process were carried out by the researcher. At the end of the 6-week process, the post-test was applied to both groups. The post-test application was applied via Google Forms. Google Forms provides the opportunity to share the academic achievement test and English lesson attitude scale with participants by creating a different access link. With these links, students accessed the academic achievement test and attitude scale towards English courses and answered the questions. The academic achievement test was applied in the last week of the experimental process. The length of the exam was one class period. The system was closed at the end of the exam duration. The questions in the speaking section of the academic achievement exam were asked by the parents and the students were asked to answer the questions and to be recorded themselves 


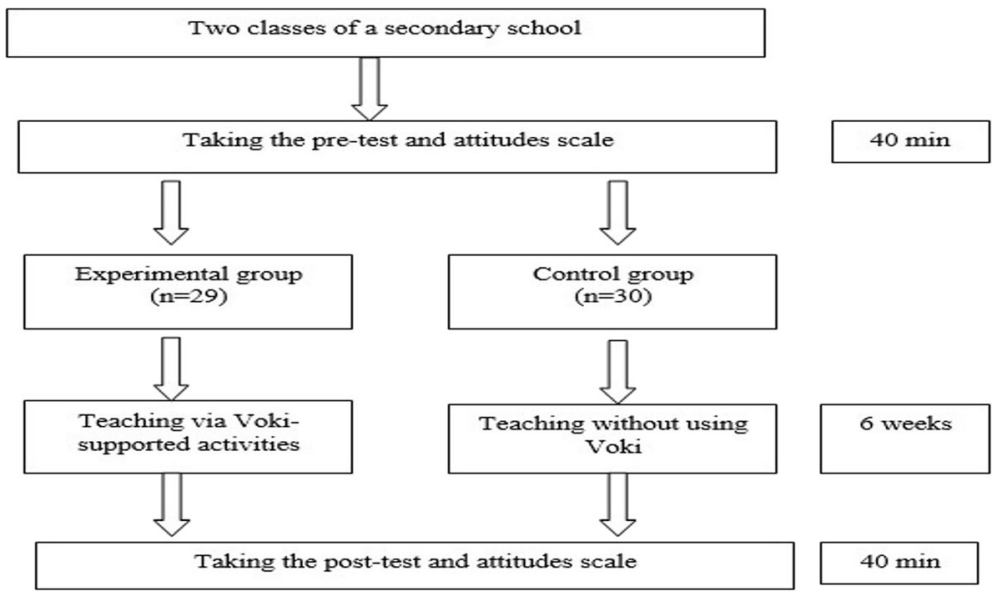

Fig. 1 Schematic diagram of the experimental design

speaking. After the academic achievement test and the attitude scale towards the English courses were applied. All students in the study group participated in the post-test application delivered via Google Forms (Fig. 1).

\subsubsection{Implementation process for the experimental group}

In the experimental group, a 6-week lesson plan was prepared to realize the acquisitions of the "Party Time" unit. The Voki lesson presentations were prepared by the researcher. Throughout the experimental process, students were encouraged to use the application with weekly assignments. Within the framework of the plan, the processing of the six-week course was carried out as follows:

1st. Week: Before starting the "Party Time" unit, the Voki character caught the students' attention by asking warm-up questions, and the students were asked to repeat the months of the year. Before starting the listening activity, the meanings and pronunciations of the unknown words and keywords in the dialogue were voiced by the Voki character (avatar) with female and male voices speaking both in British and American accents. Students were asked to create Voki with their newly learned words and present them in the lesson as an assignment (Fig. 2).

2nd Week: At the beginning of the lesson, students were shown the presentation containing the English sentence patterns using the Voki virtual presentation tool. At the end of the lesson, the same lesson content was replayed with different avatars and vocalists and so students were provided to reinforce the English sentence patterns in the unit. Through the Voki character (avatar) tool, students were asked questions about the subject, and students were encouraged to make short dialogues with the created character (Fig. 3). 


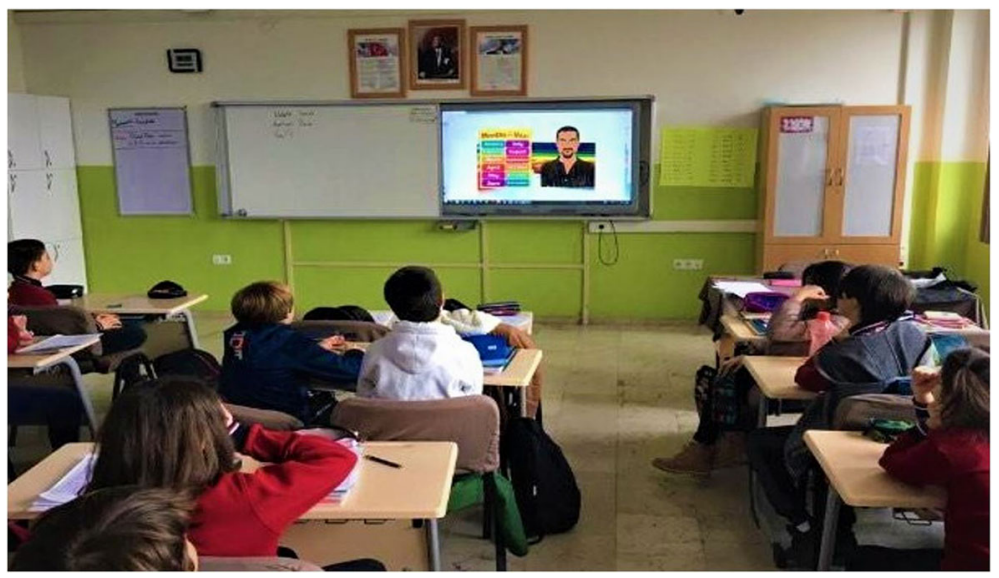

Fig. 2 Using Voki as a presentation tool in the classroom

3rd Week: Voki presentation was used to teach words and expressions of greeting and farewell. Students were asked to use the greetings and farewell expressions in different voices using different Voki avatars as an assignment (Fig. 4).

4th Week: Using the "Can" a modal auxiliary verb, the subject of asking for permission and talking about talents was explained by using Voki presentation tool. The students were asked to talk about their talents using a Voki application.

5th Week: Using the Voki presentation, students were taught about the grammatical structure" Expressing obligation" in the unit, and questions were asked about the subject. The students were asked to fill in the blanks in the text while it was read by Voki. The students were asked to present work to be done for a birthday party planning via a Voki avatar (Fig. 5).

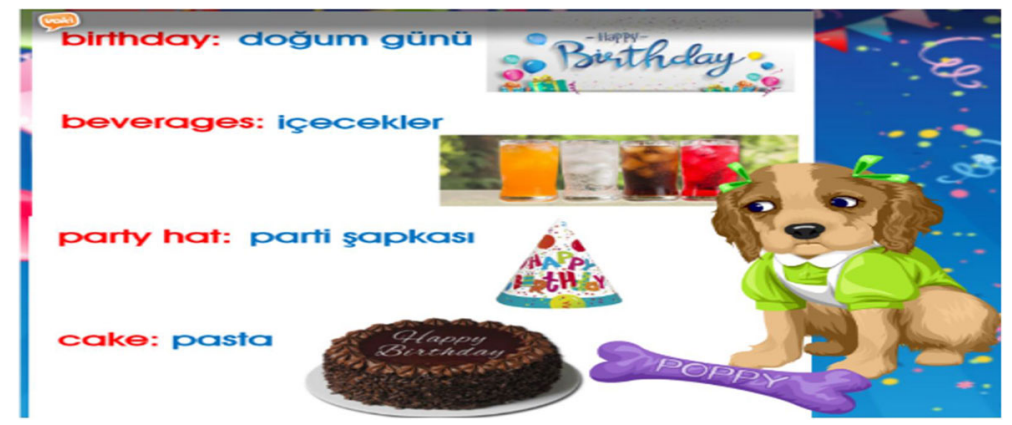

Fig. 3 Presentation of the unit words with Voki presenter 


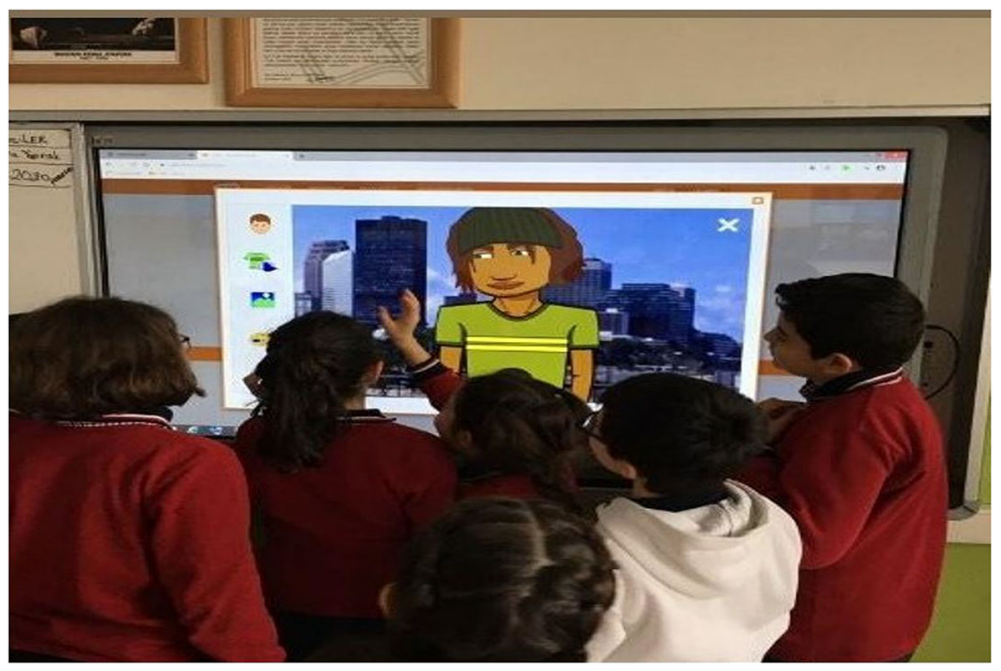

Fig. 4 Students use the Voki application during break time

6th Week: Students were asked to prepare a party invitation card and they were asked to read this invitation with a Voki character. Voki character asked the students to say the Turkish meanings of the words at the end of the unit (Fig. 6).

\subsubsection{Implementation process for the control group}

Lessons were taught in the control group through the current curriculum. These methods and techniques were used in the control group: Communicative approach: In language education, it is an approach that emphasizes interaction and communicative competence as the main goal of the study, Total Physical Response (TPR), It is a language teaching method based on the coordination of speech and action, Audiolingual method: it is a foreign language teaching method that emphasizes the teaching
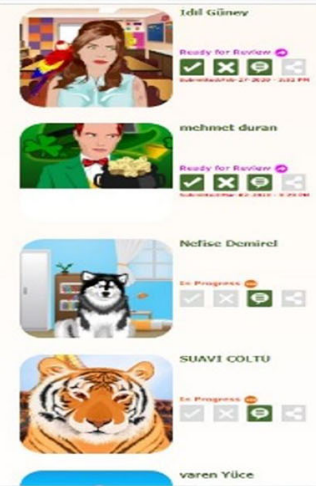

Fig. 5 Students' works in Voki classroom
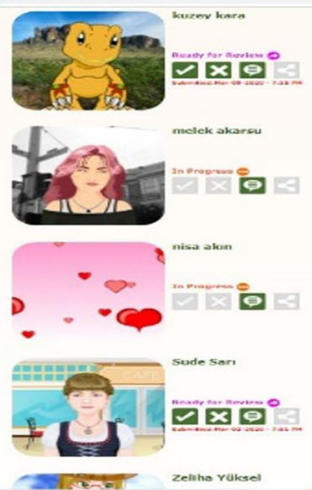
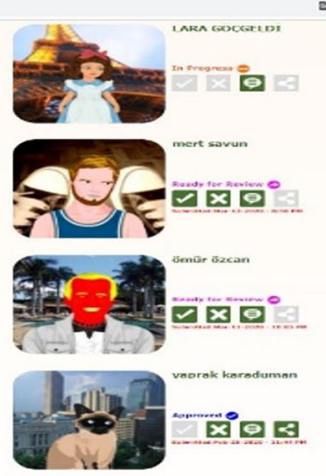


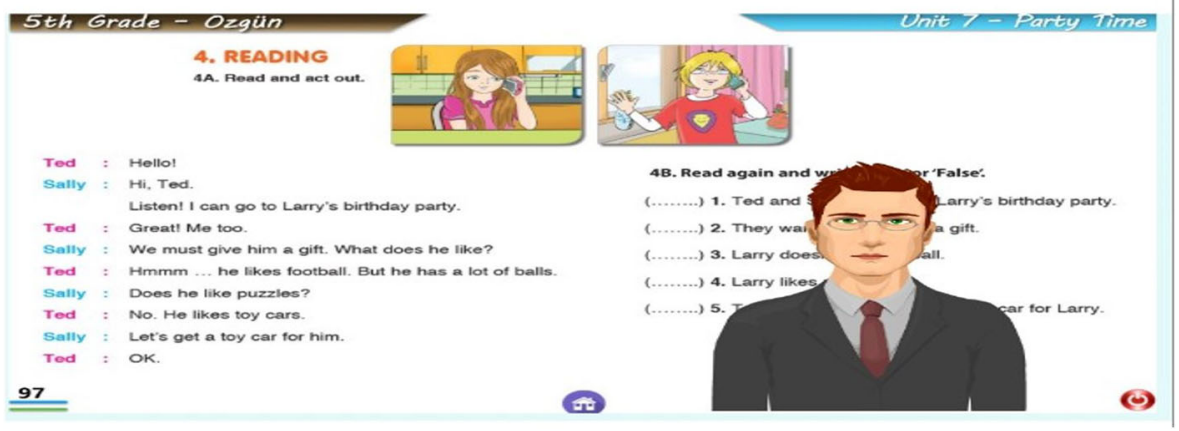

Fig. 6 Reading comprehension study with Voki character

of listening and speaking before reading and writing. The tools and equipment used are interactive board, textbooks, workshops, videos, PowerPoint presentations.

\section{1st week}

- In the Warm-up, students were taught the song of English months and then asked to write the missing months in their books and their answers were compared with their classmates.

- The song was played back to the students and asked to check their answers. Then they were asked to sing the song.

- Students were divided into groups. The students asked their friends' birthdays and wrote in the table in their books.

- Students were asked to review questions and words for new words in the unit. Explanations were made for the meanings of some words and students were asked to answer the questions in the book and then their answers were checked. Students were given a dialogue on their birthday and told to complete the dialogue with given sentences.

\section{2nd week}

- Students were asked to read the dialogue and complete the invitation card.

- The students were asked to look at the pictures in the book and complete the dialogue.

The students were paired. The dialogue was read aloud, and students were asked to make similar dialogues. The written dialogue was acted out in front of the class.

\section{3rd week}

- The students were asked to guess the unknown words and match the words with the pictures. 
- Students were asked to listen to the recording and complete the shopping list.

- The students were asked to look at the pictures. Students were asked to say what Larry and his family should do. The students talked about the things to be done using the given keywords.

\section{4th week}

- Students were told to read the given situations and asked what to do according to these situations.

- The students were asked to read the dialogue and then do the "True" "False" activity.

- The students were asked to look at the pictures and create a short dialogue.

\section{5th week}

- Students were asked to sing the song they were listening to.

- The students were asked to look at the pictures, complete the puzzle, and find the hidden message.

- They were asked to sort the months correctly.

- The students were asked to write the missing months.

\section{6th week}

- The students were asked to mark their birthday on the calendar and say it in English.

- The students were asked to look at the pictures and complete the dialogues.

- The activity of "circle the different one" was done.

\subsection{Teaching tool}

Voki is an educational tool that allows students to create their speech characters (avatars) online and this character speaks using the creator's voice, an uploaded file, or by reading a typed in a message (called text-to-speech) in different languages. Voki characters can be historical figures, cartoons, animals, and they can even be customized to look like themselves. It is a web 2.0 application that can be integrated into all lessons, especially foreign language lessons. With this application, students can make their chosen characters speak in English (Oddcast Inc., 2020). Kennedy \& Soifer (2013) defines Voki as follows: An online tool where teachers and students can design a speaking avatar, voice it out in writing, or verbally. Picardo (2009) describes it as a web 
2.0 tool in which students can create avatars in the web environment in any way they want and perform them with their voices. Lornsen (2010) described it as a web 2.0 tool that teachers can use in listening activities and dictation.

Voki app is a web-based application. The application can be used on computers, smartphones, and tablets. It allows us to create an avatar in the Android and Ios operating systems without the need for an internet connection and voice an avatar in 25 languages. The application consists of 4 different parts. These are Voki, Voki Classroom, Voki Presenter, and Voki Hangout. Voki can be used free of charge however, Voki Classroom and Voki Presenter are charged monthly or annually. The use of Voki chapters is as follows:

Voki: In this section, it is possible to design an avatar individually and to voice the designed avatar. The Avatar's appearance can be customized with the click of a mouse; its head, clothes, and accessories can be selected. Besides, Voki character can be placed in the background. The created Voki avatar can be shared on e-mail, Facebook, Twitter, website, or Blogs.

Voki Classroom: Voki class can be used in school or classroom activities. Classes can be created in Voki classroom and students can be added. Besides, the system can automatically create a username and password for students and can also be changed on demand. Each student who accesses the application has a page of their own. On this page, students can create Voki avatars and share them with their teachers, friends, and social circle. With the Voki classroom, students can be given assignments and their developments can be monitored. It is charged monthly or annually after 15 days of free trial use.

Voki Presenter: Animated presentations can be created in this section and the presentation can be more interactive by putting various Voki avatars. For example, information can be given about the historical event by creating an avatar of an important historical character; or numerical information can be given by creating an avatar of a math symbol. The student can watch the presentation with his / her family, friends, and assistant teachers at school, at home, or anywhere at any time.

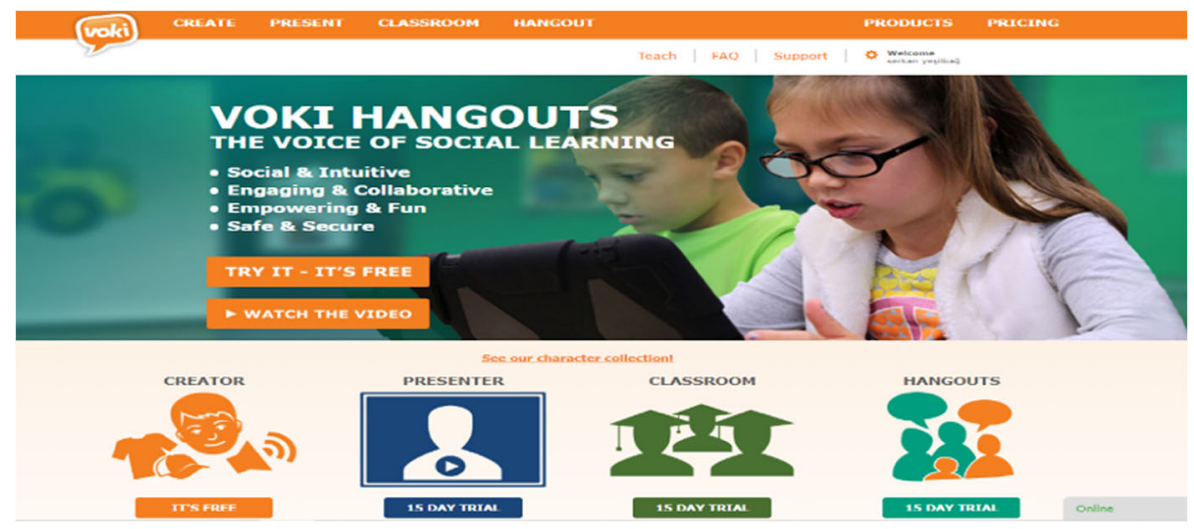

Fig. 7 Voki web page 
Voki Hangout is a moderate animated discussion forum for students. Building on empower students, self-expression, and encourage participation for online social interaction. Voki hangouts are especially helpful to students who may be scared to speak up in a classroom.

Dona, Stover, and Broughton (2014) stated that one of the digital web 2.0 technology tools that encourage creativity while learning foreign languages is Voki. Voki is a powerful and fun way to practice English speaking, listening, and writing. Language learners can record their voices and share voice messages (Aikina \& Zubkova, 2015). Regarding the implementation of Voki in the classroom, Mirtschin (2010) recommends the following tips.

- to introduce to the class (students may introduce themselves via Voki avatar)

- to introduce new materials interestingly,

- to review,

- to practice pronunciation skills (Fig. 7).

\subsection{Analysis of data}

The academic achievement test has 4 sections: listening, reading, writing, and speaking. Each section has a score range of $0-25$. These are added together for a total score of 0 100. The highest score that can be obtained from the attitude scale is 135 and the lowest score is 27 . The data should be checked if they have a normal distribution before proceeding with the analysis (Büyüköztürk, 2009). In this context, the distribution status of the data was examined, and the results were summarized in Table 6.

The data were analyzed by using SPSS 22.0. Kolmogorov-Smirnov normality analysis can be used if the sample size is larger than 50 while the normality of the distributions of the data is being tested (Büyüköztürk, 2005). Since the academic achievement pre and post-test results of the experimental and control group have a

Table 6 The results of normality analysis of students' academic achievement test and attitude towards English courses

\begin{tabular}{lllllll}
\hline Groups & & \multicolumn{2}{l}{ Kolmogorov-Smirnov } & & \\
\cline { 3 - 7 } & & Statistic & N & p. & Skewness & Kurtosis \\
\hline Pre-test academic achievement & Exp. &, 114 & 29 &, $200^{*}$ &,- 612 &, 428 \\
& Control &, 132 & 30 &, 196 &, 753 &, 247 \\
Post-test academic achievement & Exp. &, 108 & 29 &, $200^{*}$ &,- 405 &,- 635 \\
& Control &, 104 & 30 &, $200^{*}$ &,- 341 &,- 025 \\
Pre-test attitude & Exp. &, 200 & 29 &, 004 & -1002 &, 109 \\
& Control &, 111 & 30 &, $200^{*}$ &,- 515 &, 608 \\
Post-test attitude & Exp. &, 140 & 29 &, 156 &,- 536 &,- 681 \\
& Control &, 196 & 30 &, 005 &,- 553 &,- 581 \\
\hline
\end{tabular}


Table 7 Findings as regards the equivalence of groups

\begin{tabular}{llllllll}
\hline \multirow{2}{*}{ Listening } & Groups & $\mathrm{N}$ & $\bar{X}$ & $\mathrm{Sd}$ & $\mathrm{df}$ & $\mathrm{t}$ & $\mathrm{p}$ \\
& Exp. & 29 & 14,65 & 3,993 & 57 & $-1,030$ &, 308 \\
Reading & Control & 30 & 15,83 & 4,749 & & & \\
\multirow{4}{*}{ Writing } & Exp. & 29 & 9,965 & 5,454 & &, 284 &, 777 \\
& Control & 30 & 9,566 & 5,328 & & & \\
Speaking & Exp. & 29 & 6,448 & 5,748 & &,- 244 &, 808 \\
& Control & 30 & 6,766 & 4,166 & & & \\
Academic Achv. Total & Exp. & 29 & 7,103 & 2,703 & &, 481 &, 633 \\
& Control & 30 & 6,733 & 3,183 & & & \\
Attitudes & Exp. & 29 & 38,17 & 12,01 & &,- 278 &, 782 \\
& Control & 30 & 39,06 & 12,63 & & & \\
& Exp. & 29 & 107,82 & 20,98 & & 1,064 &, 292 \\
& Control & 30 & 102,66 & 16,02 & & & \\
\hline
\end{tabular}

significance value of $p>0,05$; it can be said that both groups have a normal distribution.

Considering the attitude scores of the groups towards English courses, it can be said that the control group's pre-test score and the experimental group post-test score show a normal distribution since the significance value is $p>0,05$. Since the significance value of the pre-test of the experimental group and the post-test score of the control group is $p<0,05$; skewness and kurtosis values have been examined. Since these values are between $-1,5$ and $+1,5$; it can be assumed that the data show normal distribution (Tabachnick \& Fidell, 2001). According to the results of normality analysis, the data show normal distribution. Parametric statistical tests can be used to analyze quantitative data with a normal distribution (Özdamar, 2013). To determine the effectiveness of the experimental process, the similarity of the groups was investigated before the application and summarized in Table 7.

Table 8 Impact of Voki application on academic achievement

\begin{tabular}{|c|c|c|c|c|c|c|c|}
\hline Groups & & $\mathrm{N}$ & $\bar{X}$ & $\mathrm{Sd}$ & $\mathrm{df}$ & $\mathrm{t}$ & $\mathrm{p}$ \\
\hline \multirow[t]{2}{*}{ Listening } & Exp. & 29 & 17,93 & 6,750 & 57 &,- 357 &, 722 \\
\hline & Control & 30 & 18,50 & 5,437 & & & \\
\hline \multirow[t]{2}{*}{ Reading } & Exp. & 29 & 18,03 & 5,685 & & ,638 &, 526 \\
\hline & Control & 30 & 17,10 & 5,566 & & & \\
\hline \multirow[t]{2}{*}{ Writing } & Exp. & 29 & 13,55 & 7,002 & &, 317 & ,753 \\
\hline & Control & 30 & 13,00 & 6,378 & & & \\
\hline \multirow[t]{2}{*}{ Speaking } & Exp. & 29 & 17,44 & 6,571 & & 2,44 & ,018 \\
\hline & Control & 30 & 13,40 & 6,150 & & & \\
\hline \multirow[t]{2}{*}{ Total } & Exp. & 29 & 66,96 & $2,1,56$ & & ,958 &, 342 \\
\hline & Control & 30 & 62,00 & 18,13 & & & \\
\hline
\end{tabular}


According to the data in Table 7 regarding the independent sample $t$ test, there is no significant difference in both the English academic achievement test total scores $\left(\mathrm{t}_{(2-}\right.$ 57) $=-, 278 ; p>0,05)$ and listening $\left(\mathrm{t}_{(2-57)}=-1030 ; \mathrm{p}>0,05\right)$, reading $\left(\mathrm{t}_{(2-57)}=, 284 ; \mathrm{p}>\right.$ $0,05)$, writing $\left(\mathrm{t}_{(2-57)}=-, 244 ; \mathrm{p}>0,05\right)$ and speaking $\left(\mathrm{t}_{(2-57)}=, 481 ; \mathrm{p}>0,05\right)$ of the experimental and control groups. Based on this finding, it can be said that the achievements of the experimental and control groups are equivalent before the experimental process.

According to Table 7, the attitude point of the experimental group students is $(\bar{x}=107,82)$ and the attitude point of the control group students is $(\bar{x}=102,66)$. Although the attitude scores of the experimental group are higher than the control group, this difference is not statistically significant $\left(\mathrm{t}_{(2-57)}=1064 ; p>0,05\right)$. Based on this finding, it can be said that the attitudes of the experimental and control groups to the English courses are similar before the application. In this context, it has been decided to analyze the data through arithmetic mean, standard deviation, and independent-sample t-test.

\section{Results}

The results of the effect of Voki on students 'academic achievement in English courses were summarized in Table 8 .

According to the data in Table 8; when the academic achievement total scores of the experimental and control groups have been examined; the experimental group's posttest academic achievement average $(\bar{X}=66,96)$ is higher than the control group students' achievement average $(\bar{X}=62,00)$, but this difference is not statistically significant $\left(\mathrm{t}_{(2-57)}=, 958 ; p>0,05\right)$. While there is no significant difference in listening $\left(\mathrm{t}_{(2-57)}=-, 357 ; \mathrm{p}>0,05\right)$, reading $\left(\mathrm{t}_{(2-57)}=, 638 ; \mathrm{p}>0,05\right)$, writing $\left(\mathrm{t}_{(2-57)}=, 317\right.$; $p>0,05$; however, in the speaking section, it has been observed that the average score of the students in the experimental group is $\bar{X}=17,44$ while the average score of the students in the control group is $\bar{X}=13,40$. This difference is statistically significant in favor of the experimental group $\left(\mathrm{t}_{(2-57)}=2,44 ; p<0,05\right)$. The results indicate that the Voki application does not have a significant effect on the groups' level of listening, reading, and writing. However, regarding the speaking section, students in the experimental group reached a significantly higher achievement level than those in the control group.

The findings regarding the contribution of Voki application to students' attitudes towards English courses were summarized in Table 9.

According to the data in Table 9, the attitude scale scores of the students in the experimental group were $\bar{X}=103,89$ while the average score of the students in the

Table 9 The effect of Voki application on attitude towards English courses

\begin{tabular}{lllllll}
\hline Group & $\mathrm{N}$ & $\bar{X}$ & $\mathrm{sd}$ & $\mathrm{df}$ & $\mathrm{t}$ & $\mathrm{p}$ \\
\hline Exp. & 29 & 103,89 & 23,37 & 57 &, 366 &, 716 \\
Control & 30 & 101,96 & 16,65 & & & \\
\hline
\end{tabular}


control group was $\bar{X}=101,96$. According to the independent sample t-test result, the post attitude score averages of the experimental group are higher than the control group, but this result is not statistically significant $\left(\mathrm{t}_{(2-57)}=, 366 ; p>0,05\right)$. In other words, it can be said that there is no significant difference between the post-test scores of the experimental and control groups.

\section{Conclusions and discussion}

At the end of the experimental process, when the total academic achievement scores of the students were examined, it was observed that the academic achievement averages of the experimental group students were higher, but this was not statistically significant. When the results of the academic achievement test in listening, reading, writing and speaking were examined, the average of the students' productive skills (writing, speaking) was lower than the receptive skills (listening, reading); therefore, it was found that there was not much increase in the general achievement averages of the groups. A lack of competence in any of four basic language skills (Al-Nasser, 2015), four basic skills are not included in measurement and evaluation, so students do not consider it necessary to learn skills that are not measured (Paker, 2012), the development of students' perception of foreign language learning in this direction can be shown among the reasons.

Listening, reading, speaking, and writing levels of both groups were close to each other before the application. After application, there was no significant difference between the total scores as well as the listening, reading, and writing sections of the groups however, it was determined that it contributed significantly to speaking skills. In other words, it can be said that the students of the experimental group who were taught with Voki-supported activities achieved a more successful result in the section of the speaking. Similar findings were found in the studies conducted on the effect of Voki tool on speaking skill: In Ramdani's (2018) study on using Voki to support first-year students' English as a foreign language, he stated that it is beneficial for students' speaking skills. Zargaryan (2012) examined the effect of Voki application on students' speaking skills. As a result of her experimental study, she stated that Voki may be a suitable method for foreign language students to improve their speaking skills, that students' attitudes towards this tool are positive because it provides an effective and fun learning environment where they can improve their speaking skills. Manty, et al. (2017) conducted action research on the use of Voki as a teaching tool in foreign language learning and perceptions of students using Voki to improve their speaking skills. Voki application incorporated into the teaching of English for 4 weeks. During the 4 weeks, the researcher gave homework and feedback to the students. At the end of the application, he concluded that Voki helped in improving students' speaking skills in terms of fluency and pronunciation. He also stated that the Voki tool encouraged the students to participate in the learning process.

In the literature, it has been investigated whether Voki tool has an effect on speaking and pronunciation skills in foreign language teaching in general and it is emphasized that Voki improves speaking practice and it can be useful to improve pronunciation 
skills (Setyawati \& Azizaturrohmah, 2016; Özdemir, 2017; Ramdani, 2018; Zargaryan, 2012; Manty et al., 2017). It is also stated that this positive result may be due to many reasons: The Voki tool motivates the student to speak, creates a fun learning environment, and allows them to learn and perform pronunciation studies outside the classroom. These factors can be shown among the reasons for the success achieved.

At the end of the experimental process, it was investigated whether there was a change in the attitudes of the experimental and control group students towards English courses. When the attitude scores of the groups were examined, it was determined that there was a decrease in the attitudes of groups towards English courses and there was no significant difference between the groups. When the researches about the use of Voki tool in foreign language education are examined; In the studies of Bellés-Calvera and Bellés-Fortuño (2018) investigating students' attitudes towards the use of information and communication technology tools in pronunciation learning, they stated that Voki tool had a positive effect on students' attitudes. This is because they stated that the students think that the Voki tool is useful in pronunciation training and using the Voki tool may decrease the number of misspelled words. In Zargaryan's (2012) study, she stated that students had a positive attitude towards Voki practice because it provides a fun and effective learning environment to improve students' speaking skills. She also stated that the students put forward many different learning strategies when creating Voki. In foreign language teaching, it has been observed that there are a limited number of studies on the effect of Voki tool on student attitudes, and as a result of these studies, positive results were obtained in students' attitudes towards speaking skills.

When the studies on determining the effect of Voki tool on student attitude were examined in the literature, it was seen that students' attitudes towards Voki application and speaking skills increased. However, in this study, Voki application did not cause an increase in students' attitudes towards English courses. In this respect, it is not consistent with the findings of previous studies. Possible causes of this situation are that the academic achievement test was developed and implemented as a scale that measures four basic skills, but such measurement had not been applied before; the experimental process was completed in 6 weeks, but it was not considered sufficient to affect student attitudes The fact that change in attitudes is difficult supports this idea (Gatewood, Feild, \& Murray, 2015). In the experimental process, students' intensive studies involving four basic skills in English may have negatively affected their attitudes (Cenoz, 2009). Another factor is the effect of linguistic skills on attitudes (Cargile, Giles, Ryan, \& Bradac, 1994). The fact that students have language skills at the beginner level may have affected their attitudes in some cases because they were exposed to intensive English in some cases where they could not respond to basic commands. Besides, students may have difficulties in the writing section of their tests, and this may have prevented their attitudes from increasing (Karatay \& Kartalloğlu, 2016). Indeed, the necessity of acquiring writing skills can affect students' achievements and motivations. Students who feel unable to express their thoughts in writing may develop a negative attitude towards language learning (Çakır, 2010). This situation can be interpreted as the reason why the experimental group students did not change their attitudes towards English courses although they found positive in a different learning environment. In this study, it was observed that Voki, one of the Web 2.0 tools helped in the improvement of the experimental groups' speaking skills at the "Party Time" unit. Therefore, web 2.0 tools such as Voki, which will keep the student 
at the center of the learning process, should be utilized alone or in combination with teaching methods in foreign language courses. Web 2.0 technologies could help educators provide more opportunities to expose students to such practices inside and outside of the classroom.

\section{References}

Abdullah, S. (2015). Challenges for teaching English as a second language and their remedies. International Journal of Humanities and Management Sciences (IJHMS), 3(6), 371-373.

Acat, B. M., \& Demiral, S. (2002). Sources of motivation in learning foreign language in Turkey. Educational Administration In Theory and Practice, 8(3), 312-329.

Aikina, T., \& Zubkova, O. (2015). Integrating online services into English language teaching and learning: The case of Voki. International Journal of Emerging Technologies in Learning (iJET), 10(3), 66-68. https://doi.org/10.3991/ijet.v10i3.4546.

Al-Kathiri, F. (2015). Beyond the classroom walls: Edmodo in Saudi secondary school. English Language Teaching, 8(1), 189-204.

Al-Nasser, A. S. (2015). Problems of English language acquisition in Saudi Arabia: An exploratory-cumremedial study. Theory and Practice in Language Studies, 5(8), 1612-1619.

Arikan, A., \& Özel, A. G. (2015). The use of the internet and web 2.0 tools among Efl instructors. Mediterranean Journal of Humanities, 5(1), 313-325.

Balc1, A. (2001). Sosyal bilimlerde araştırma yöntem teknik ve ilkeler [research methods, techniques and principles in social sciences ]. Ankara: Pegem Yayıncilık.

Baş, G. (2012). Attitude scale for elementary English course: Validity and reliability. International Online Journal of Educational Sciences, 4(2), 411-424.

Baş, B., \& Yıldırım, T. (2018). Technology integration in teaching Turkish as a foreign language. Journal of Mother Tongue Education, 6(3), 827-839.

Bellés-Calvera, L., \& Bellés-Fortuño, B. (2018). Teaching English pronunciation with OERs: The case of Voki. Sintagma: Revista de Lingüística, 2018(30), 57-80.

Bodur, G. Y., \& Arikan, A. (2017). Why can’t we learn English?: Students’ opinions at Akdeniz University. Gaziantep University Journal of Educational Sciences, 1(1), 1-7.

Boz, M. S., \& Çoban, Ö. (2015). Yabancı dil eğitiminde teknoloji kullanımı [Using technology in foreign language education]. Retrieved from https://yegitek.meb.gov.tr/meb_iys_dosyalar/2018_11/ 06104720_Yabanci-Dil-Egitiminde-Teknoloji-Kullanimi-2015_SerpilYmYr_hoca.pdf.

British Council. (2020). Monster shopping trip. Retrieved February 13, 2020, from British Council LearnEnglish kids: https://earnenglishkids.britishcouncil.org/short-stories/monster-shopping-trip.

Brown, N., McIlwraith, T., \& González, L. T. (2020). Globalization (2nd ed.). Virginia: Perspectives: An open introduction to cultural anthropology. Retrieved from https://perspectives.pressbooks.com/chapter/ globalization/.

Büyüköztürk, Ș. (2005). Sosyal bilimler için veri analizi el kitabı istatistik, araştırma deseni SPSS uygulamalarl ve yorum [data analysis handbook for social sciences statistics, research design SPSS applications and interpretation]. Ankara: Pegem Akademi Yayıncilı.

Büyüköztürk, Ș. (2009). Bilimsel Araştırma Yöntemleri [scientific research methods] (4th ed.). Ankara: Pegem Akademi.

Büyüköztürk, Ș. (2014). Bilimsel araştırma yöntemleri [scientific research methods]. Ankara: Pegem Akademi.

Çakır, İ. (2010). Why is writing skill difficult to gain in foreign language teaching. Institute of Social Sciences Journal, 28, 165-176.

Cambridge Dictionary. (2020). Retrieved March 5, 2020, from Cambridge University Press 2020: https:// dictionary.cambridge.org/tr/s\%C3\%B6zl\%C3\%BCk/ingilizce/web-20?q=web+2.0.

Cargile, A. C., Giles, H., Ryan, E. B., \& Bradac, J. J. (1994). Language attitudes as a social process: A conceptual model and new direction. Language \& Communication, 14(3), 211-236.

Çarıkcığlu, M. (2019). The view of the teachers and students about problems in the process of applying 2018 English curriculum. Unpublished Master's Thesis. 
Cenoz, J. (2009). Towards multilingual education basque educational research from an international persfective (Vol. 72). Multilingual Matters: Basque educational research from an international perspective.

Chakowa, J. (2018). Enhancing beginners' second language learning through an informal online environment. Journal of Educators Online, 15(1), 1-14.

Çınar, İ. (2007). Ulusal Dil, Ana Dili ve Eğitim Dili [national language, mother tongue and education language]. Eğitişim Journal, 15. Retrieved from http://www.egitisim.gen.tr/tr/index.php/arsiv/sayi-1120/sayi-15-fen-egitimi-mayis-2007/182-ulusal-dil-ana-dili-ve-egitim-dili.

Demirel, Ö. (1990). Yabancı dil ögretimi ilkeler, yöntemler, teknikler [foreign language teaching principles, methods, techniques] (p. 6). Ankara: Usem Yayınları.

Demirel, Ö. (2019). Yabancl dil ögretimi [Foreign language teaching] (10th ed.). Ankara: Pegem Akademi yay. Eğt. Dan. Hizm. Tic. AȘ.. https://doi.org/10.14527/9789756802090.

Demirpolat, B. C. (2015). Türkiye'nin yabancı dil öğretimiyle imtihanı: Sorunlar ve çözüm önerileri [The challenge for Turkey's foreign language teaching: Problems and solutions]. SETA.

Dona, E., Stover, S., \& Broughton, N. (2014). Modern languages and distance education: Thirteen days in the cloud. Turkish Online Journal of Distance Education, 15(3), 155-170.

Durusoy, O. (2011). Developing the teachers' self-efficacy through web 2.0 technologies and digital videos in teacher training. Unpublished Master's Thesis.

Gatewood, R., Feild, H. S., \& Murray. (2015). Human resource selection (8th ed.). USA: Nelson Education.

Gömleksiz, M. N., \& Düşmez, O. S. (2005). A comparison of computer assisted language learning and traditional method on student's achievement in teaching relative clauses. Turkish Educational Sciences Journal, 3(2), 163-179.

İnce, M., \& Akdemir, Ö. (2013). The investigations of using web 2.0 technologies on English writing skills of students with different learning styles. Eurasian Journal of Educational Research, 53/A, 93-106.

Karakuș, B. (2013). Assessment and evaluation in modular system being practised in university foreign language preparation classes. Journal of Research in Education and Teaching, 2(4), 15-22.

Karasar, N. (2004). Bilimsel Araştırma Yöntemi[scientific reseach methods] (24th ed.). Ankara: Nobel Yayinlar1.

Karatay, H., \& Kartallığlu, N. (2016). The relation between the attitude of learning Turkish as foreign language and acquisition of language skills. Journal of Abant İzet Baysal University Institute of Social Sciences, 16(4), 203-213.

Kaynar, T. (2019). The use of web 2.0 education tools in foreign language learning. Unpublished Master's Thesis, İstanbul.

Kennedy, S., \& Soifer, D. (2013). Technology-driven innovations for teaching English learners. Arlington, VA: Lexington Institute.

Korucu, A. T., \& Cakir, H. (2015). The opinions of the teacher candidates using collaborative learning environment developed via dynamic web technologies. Adiyaman University Journal of Social Sciences, 19, 221-254. https://doi.org/10.14520/adyusbd.61147.

Levy, M. (2009). Technologies in use for second language learning. The Modern Language Journal, 93(1), $769-782$.

Lornsen, T. (2010). Free web 2.0 tools in German language classes. Die Unterrichtspraxis / Teaching German, 43(2), 200-2002.

Manty, M., Yunus, M. M., Badusah, J., \& Shah, P. M. (2017). Using voki to enhance speaking skills. STEd 2017 (pp. 668-672). Prosiding Seminar Pendidikan Transdisiplin. Retrieved from https:// sted18.files.wordpress.com/2016/12/4-11-michelle-manty-melor-md-yunus-jamaludin-hj-badusahparilah-m-shah.pdf.

Mirtschin, A. (2010). Cool tools for the connected classroom Australia. Carlton South, Victoria: Education Services.

Mohammed, M. H. (2018). Challenges of learning English as a foreign language (efl) by non-native learners. International Journal of Social Science and Economic Research, 3(4), 1381-1400.

O'Reilly, T. (2005). O'Reilly media, Inc. Retrieved from https:/www.oreilly.com/pub/a/web2/archive/whatis-web-20.html.

Oddcast Inc. (2020). About Voki. Retrieved January 12, 2020, from Voki: http://www.voki.com.

Özdamar, K. (2013). Paket programlar ile istatistiksel veri analizi [statistical data analysis with package programs]. Eskișehir: Nisan Kitabevi.

Özdemir, O. (2017). Usage of digital technologies in Turkish teaching and an example of web implementation. Electronic Turkish Studies, 12(4), 427-444. 
Paker, T. (2006). Çal bölgesindeki okullarda İngilizce öğretiminin sorunları ve çözüm önerileri [problems of teaching English in schools in Çal region and suggested solutions]. Denizli. Retrieved from http:// hdl.handle.net/11499/3760.

Paker, T. (2012). Türkiye'de neden yabancı dil (ingilizce) öğretemiyoruz ve neden öğrencilerimiz iletișim kurabilecek düzeyde İngilizce öğrenemiyor? [why do not we teach a foreign language in Turkey and why can't our students learn English enough to communication]. Pamukkale University, Journal of Education Faculty, 32, 89-94. https://doi.org/10.9779/PUJE563.

Paker, T., \& Höl, D. (2012). Attitudes and perceptions of the students and instructors towards testing speaking communicatively. Pamukkale Üniversitesi Ĕ̈itim Fakültesi Dergisi, 32(2), 13-24.

Picardo, J. (2009). Using Blogs and Voki to increase motivation and oral participation amongst boys in Modern Foreign Languages. Retrieved from https://www.slideshare.net/boxoftricks/using-blogs-andvoki-to-increase-motivation-and-oral-participation-amongst-boys-in-modern-foreign-languages.

Punthumasen, P. (2007). International program for teacher education: An approach to tackling problems of English education in Thailand. The 11th UNESCO-APEID International Conference Reinventing Higher Education:Toward Participatory and Sustainable Development, (pp. 1-14). Bangkok, Thailand.

Ramdani, A. S. (2018). The use of Voki as a media to support the enhancement of first grade students speaking skills at SMPN 4 Tambun Selatan. Jurnal Inovasi Pendidikan MH Thamrin, 2(1), 12-25.

Roumen, V., \& Grego, J. (2012). Duolingo effectiveness study. City University of New York, USA, 28, 1-25 Retrieved from http://static.duolingo.com/s3/DuolingoReport_Final.pdf.

Șahin, T. Y., \& Yıldırım, S. (1999). Öğretim teknolojileri ve materyal geliştirme [instructional technologies and material development]. Ankara: Anı Yayıncılık.

Setyawati, H., \& Azizaturrohmah, N. (2016). Teaching English for 21st century students :Using "voki” in speaking class. Current Trends on Research Methodology in English Language Teaching, 236-243. Retrieved from http://english.stkipbjm.ac.id/wp-content/uploads/2017/04/Heny-Setyawati.pdf.

Songbatumis, A. M. (2017). Challenges in teaching English faced by English teachers at MTsN Taliwang, Indonesia. Journal Foreign Language Teaching\&Learning, 2(2), 54-67.

Suna, Y., \& Durmușçelebi, M. (2013). A compilation work about why Turkey suffers from learning and teaching English. OPUS-International Journal of Society Researches, 3(5), 31-48 Retrieved from https:// dergipark.org.tr/en/pub/opus/issue/22693/242282.

Tabachnick, B. G., \& Fidell, L. S. (2001). Using multivariate statistics (4th ed.). Boston: Pearson.

Ușun, S. (2000). Özel ögretim teknolojileri ve materyal geliştirme [Special instructional technologies and material development]. Ankara: Pegem.

Yazar, İ. (2019). The importance of digital technology applications in teaching Turkish and basic language skills. The Journal of International Social Research, 12(64), 613-623. https://doi.org/10.17719 jisr.2019.3384.

Yona, S., \& Marlina, L. (2014). The use of Voki website in teaching speaking on oral descriptive text for junior high school students. Journal Of English Language Teaching, 3(1), 235-242.

Yunus, M. M., Kwan, L. S., \& Noriah, M. I. (2012). Benefits of using web 2.0 technologies for English language learning: Gifted students' perception. In Proceedings of the 3rd International Conference on Arts and Culture (ICAC'12), Advances in Environment, Computational Chemistry and Bioscience, pp. 385390.

Zargaryan, T. (2012). The impact of Voki on EFL learners' speaking performance. LAP LAMBERT Academic Publishing, pp. 6111-6120.

Publisher's note Springer Nature remains neutral with regard to jurisdictional claims in published maps and institutional affiliations. 